\title{
Notes
}

1. C. Paul Petersen is the form of listing found for all his entries in Lovell's Montreal Directory.

2. Biographical information supplied by his son Ole Petersen from an interview on February 13, 1996.

3. Idem.

4. Information supplied by former Vice-Principal (Academic) Eigil Pedersen, October 15, 1995.

5. Idem.

6. Montreal Gazette, July 5, 1994.

\section{In Their Own Write: An Exhibition Celebrating 175 Years of McGill Authorship}

\author{
By David McKnight \\ Reference Librarian, McLennan Library
}

In her 1991 essay "A Torch for All Time" Carol Martin remarks: "Study, analysis, and research-the desire to push back, bit by bit, the frontiers of knowledge. These are the forces that lie at the heart of every great. university. "1 Although it was not apparent 175 years ago that McGill would, in time, evolve into a great university, history has judged otherwise.

Indeed, as the 19th century drew to a close, McGill had emerged as an institution with great promise due to the efforts of the "Three Williams:" William Dawson, Sir William Osler, and Sir William Peterson. Each in their own way played key roles in laying the foundation of McGill as a world-class university. As the second Millennium draws to a close the record of scholarly achievement is now secure. And yet, one thing is constant since James McGill set in motion the founding of the Royal Institution for the Advancement of Learning in 1821, then as now, the institution now know as McGill University is beset with new challenges which strike to the very core of its existence.

One of the current key issues is how McGill will adapt to the global information revolution which is manifestly changing the essence of scholarly communication. Scholarly communication is, of course, the matrix of print documents-learned journals, proceedings, and the books, which have served as the primary media of expression for researchers and scholars since the rise of the modern research university at the end of the last century.

Certainly it is too early to judge what the long term effects of electronic publishing will have upon the university community. Just as the spread of printing throughout Europe at the end of the 15 th century gradually replaced handlettered books, electronic books and journals may in time become the primary medium for the transmission of knowledge rendering the printed word rarefied or quaintly antique. As for the immediate future, it is doubtful that scholars and researchers will soon abandon the ritual and necessity of scholarly publishing which is integral not only to the creation of new knowledge, but also the means of measuring and advancing academic careers.

This latter concern, the advancement of an academic career, is today commonly referred to as the 'publish or perish" syndrome. Since mid-century scholarly publication has been a major component in the tenure granting system and has been the proliferation of scholarly journals and monographs despite the appearance of counter-trends which include the high cost of journals and monographs, and the shrinkage of public funding for academic presses. The impact has been felt in the arts as well as the sciences.

On the occasion of McGill's 175th anniversary the Humanities and Social Sciences Library is going to celebrate the printed book. Drawing from its various collections, an exhibition will be held to highlight some of the great, enduring and curious books published by McGill professors, scholars and graduates during the university's long and distinguished history. The number and variety of works published by McGill authors is such that works of poetry 
and fiction have been included in the exhibition.

In honour of the 175th anniversary, McGill's Osler Library of the History of Medicine will also mount an exhibition. The Humanities and Social Sciences Library exhibition conscientiously displays both authorial creativity and the book as objet d'art. In keeping with the spirit of the University the exhibition is decidedly multidisciplinary. Works from the sciences, medicine, law, humanities and social sciences are represented. They represent in their totality the forces which define two of the intellectual cornerstones of this university: research and publication.

The exhibits are divided into three groupings: 1) Advancement of Learning, 2) Researches, 3) The Pattern of Research. The first section examines books published between 1845 and 1900, the second includes works published from 1901 to 1971, and the third section covers works which have appeared since 1972. The titles of the second and third sections are derived from a list of published "researches" by McGill professors and librarians which appeared at the turn of the century in an appendix to the McGill University Annual Report. By 1971. the number of scholarly publications had grown to such an extent that it was decided to issue the listing of McGill authored publications under a separate title: The Pattern of Research. The first volume appeared in 1972.

Over 40 authors are represented in the exhibition, among whom are names most often associated with McGill--Sir William Osler, Ernest Rutherford and Stephen Leacock. Indeed, given the rich holdings of Osler and Leacock material one could devote an entire exhibition to these individuals alone. Other notables include McGill principals: William Dawson, Sir William Peterson, and F. Cyril James. Well-represented are the members of the influential McGill Movement, consisting of A.J.M. Smith, F.R. Scott, Leon Edel, and John Glassco. Of the four, Scott was the only member who remained at McGill to pursue a distinguished career in the Law Faculty. The others are no less remarkable for their contributions to literary scholarship and letters. Another notable McGill author is Hugh MacLennan who began his 30-year association with McGill in 1951.

The earliest book on display is Joseph Abbott's Philip Musgrave published in 1845, the most recent work is Yvan Lamonde's biography of 19th century liberal and anti-clerical seigneur, Louis-Antoine Dessaules. Among the more unusual works in the exhibition is that written by R.M. Bucke. Bucke graduated from McGill's medical school in 1862. In 1877, he fell under the influence of the American poet Walt Whitman. The result of this meeting was an enduring friendship between Bucke and Whitman and the publication in 1901 of Bucke's Cosmic Consciousness. The book remains in print today.

A book with an unusual publishing history is John Clark Murray's The Industrial Kingdom of God. Although the work was completed in manuscript in 1887 it was not published until 1981. Born in Scotland, Murray was appointed professor of logic at McGill in 1872. Murray remains little-known today and his major philosophical work was published almost a century after its completion. Within the context of McGill, he is best remembered for engaging Principal Dawson in an emotional and vituperous debate concerning the education of women at McGill. Dawson held the view that women should be educated in a separate college; Murray, in contrast, believed in co-education. Dawson's view prevailed. Of course, McGill has produced a number of notable women authors, among them Maud Abbott, Margaret Gillett and Anne Carson.

In another 175 years, no doubt, this note will appear in digital format and praise the electronic words written by McGill scholars, with faint mention of the printed books which have played an important role in advancing the careers of the many McGill authors during its first 175 years. It also pays homage to the printed objects which serve as the artifacts of record which reveal the human mind and imagination as expressed in the works written by men and women associated with McGill University 'in their own write.'

\section{Notes}

1. Martin, Carol. "A Torch for All Time." In McGill: A Celebration. Montreal: McGill-Queen's Press, 1991, p. 103. 